\title{
Recovering Wood Waste to Produce Briquettes Enriched with Commercial Kraft Lignin
}

\author{
Carlos Eduardo Silveira da Silva1 ${ }^{10}$, Fernando José Borges Gomes ${ }^{*}{ }^{\circledR}$, \\ Larisse Aparecida Ribas Batalha1 (ㄷ, Roberto Carlos Costa Lelis ${ }^{1}$ (i), \\ Ana Márcia Macedo Ladeira Carvalho ${ }^{2}$ (D) Angélica de Cássia Oliveira Carneiro ${ }^{2}$ (D), \\ Alexandre Monteiro de Carvalho 1 (i) \\ ${ }^{1}$ Federal Rural University of Rio de Janeiro, Forest Products Department, Rio de Janeiro, Brazil \\ ${ }^{2}$ Federal University of Viçosa, Forest Engineer Department, Viçosa, Minas Gerais, Brazil \\ Email: c.eduardo_silveira@yahoo.com.br, ^fernandogomes@ufrrj.br, larisse.arb@gmail.com, \\ lelis@ufrrj.br, amcarvalho.ufrrj@gmail.com, ana.marcia@ufv.br, cassiacarneirol@gmail.com
}

How to cite this paper: da Silva, C.E.S., Gomes, F.J.B., Batalha, L.A.R., Lelis, R.C.C., Carvalho, A.M.M.L., de Cássia Oliveira Carneiro, A. and de Carvalho, A.M. (2021) Recovering Wood Waste to Produce Briquettes Enriched with Commercial Kraft Lignin. Natural Resources, 12, 181-195. https://doi.org/10.4236/nr.2021.125013

Received: February 21, 2021

Accepted: May 28, 2021

Published: May 31, 2021

Copyright $\odot 2021$ by author(s) and Scientific Research Publishing Inc. This work is licensed under the Creative Commons Attribution International License (CC BY 4.0).

http://creativecommons.org/licenses/by/4.0/

\section{(c) (i) Open Access}

\begin{abstract}
Aiming to use lignocellulosic biomass as energy source, one of the process that may aggregate values is the densification process, which allows the production of bioenergy using solid fuels, mainly for reducing transportation costs. In this research, solid fuel from co-briquetting of wood residues from sawmill using commercial kraft lignin as binder was investigated. The effects of compression pressure (900, 1200 and 1500 PSI) and briquette formulation (varying wood and kraft lignin proportion) on the quality and characteristics of briquettes were evaluated. The main findings were that briquetting of wood residues with kraft lignin resulted in an improvement of bulk density, strength rupture modulus, low heating value (LHV) and high heating value (HHV). The briquettes using $4 \%$ and $6 \%$ of kraft lignin, and submitted to 1200 to 1500 PSI, presented higher bulk density and strength resistance, respectively. On the other hand, the heating values showed the highest results with the addition of $2 \%$ lignin at 900 PSI, being the legal range for additives in briquettes for many countries such as in European Union.
\end{abstract}

\section{Keywords}

Hardwood Biomass Densification, Heating Values, Solid Fuel

\section{Introduction}

Lignocellulosic biomass is considered a renewable and alternative material as a potential energy source for the society [1] [2] [3] [4] [5]. The renewable supplies rank fourth in the world total energy demand after oil, coal, and natural gas [6] 
[7], being biomass the most significant type of renewable supply and due to its advantages of being widely sourced, sustainable, and environmentally friendly, it has attracted more and more interest of academic and industrial sectors [8]. Considering the concerns on the rational utilization of the lignocellulosic biomass by our society, wood processed in the sawmills, which is a common activity in many countries, is another neglected raw material, since it is available in a large volume. In these activities, the wood is poorly used, with around $40 \%$ $60 \%$ of waste being generated from the log wood processing [9], which in general is burned in the sawmills to generate energy or discarded into landfills [10].

A challenge for using waste lignocellulosic biomass is that it must be transported from where they are generated, often in milling sites and open fields, to the storage facilities, which may affect the energy balance and costs [11] [12] [13] [14] [15]. One effective strategy to address these concerns is through mechanical densification of the biomass. Mechanical densification is the compaction of biomass to definite sizes, which improves the bulk densities and minimizes the irregularities in shape of biomass, facilitating the transportation [16]. In lignocellulosic biomass processing for the production of solid fuel, pelletizers and briquette press are the most commonly used equipment for mechanical densification. These solid fuels are frequently used as substitute fuels in boilers to produce steam that may be used for electricity production, for example.

Kaliyan \& Morey [16] and Ajiboye et al. [17] support that as a result of the shape and size, among other variables, can determine the compressibility and the products of the densification. Briquettes with higher density values, produced from agriculture and forest residue, may substitute or compliment solid fuels such as charcoal, firewood and coal. The briquettes are high energy density materials, require lower transportation and storage costs, present uniform quality such as constant humidity content, and high mass fluency [18] [19].

Several studies have experimentally investigated the characteristics of alternative biomass briquettes, as wood residues, under different conditions of pressure. The results show that the sawdust, most abundant waste or residue in wood-based industries [20], may generate briquette with better characteristics than other materials [21].

Aiming to improve the mechanical and physico-chemical properties of the solid fuel, many organic and inorganic binders may be used for the densification process [22] [23] such as starch, protein, fiber, fat/oil, and other additives. The addition of binders in the densified solid fuel production using lignocellulosic biomass as raw materials might have a positive outcome on the strength, in a similar way to the resins used in the production of wood boards [24] [25].

Considering the available materials from the based forest industry that could be used for bindering purpose, the kraft lignin appears as a promissory material, since it is a hydrophobic compound and it also presents a higher heating value when compared to the whole lignocellulosic biomasses [26] [27] [28] [29] [30]. The worldwide lignin production is approximately 50 million tons [31] and this 
by-product have distinct adhesive characteristics and may be used as a densification binder [29]. The use of lignin as binder is relatively new and studies of this application as a binder have been done recently [28] [29] [32]-[38]. The resulting briquettes would cost less to transport, easier to handle and storage [39].

Regarding the available lignocellulosic biomasses for being used as raw materials, the residual material of the industrial processes seems to be an alternative for improving the rational utilization of the natural resources. Concerning the specie of wood, Astronium concinnum (Engl.) Schott, a hardwood species, belongs to the family of Anacardiaceae, commonly known as gonçalo-alves, aroeira-rajada, guarubu-violeta and mucuri, which is a raw material widely used commercially due to its wood quality and availability [40]. Its wood is more used in exteriors, buildings, floors and furniture [41] [42] [43] and its basic density value is around $0.64 \mathrm{~g} / \mathrm{cm}^{3}[44]$.

The main goal of this research was to evaluate the application of common woody industrial waste from sawmills (sawdust of Astronium Concinnum (Engl.) Schott) enriched with eucalypt kraft lignin as an additive, aiming to produce briquettes.

\section{Materials and Methods}

\subsection{Raw Materials}

In this work residues from the wood sawmill processing Astronium concinnum (Engl.) Schott were used. The wood samples evaluated were 37 years old. Three trees samples were collected from an experimental station in the Vale Natural Reserve, which is inside the Atlantic Forest biome, located in Sooretama, Espírito Santo State, Brazil. The residues were obtained from a machining process commonly used on a sawmill. The residues (sawdust) were collected and air dried to a moisture content of about $15 \%$ and stored in plastic bags. The commercial kraft lignin used as an additive in the briquetting process was obtained from a Brazilian kraft pulp mill, Suzano Pulp and Paper, which uses Eucalyptus spp. as feedstock.

\subsection{Methods}

The wood biomass, commercial kraft lignin and briquettes were characterized according to the methods described in Table 1 .

The briquetting process was conducted using a laboratory briquette machine with a piston press (LB-32, Lippel, Brazil). The briquetting conditions were determined experimentally through preliminary tests of pressure application and the time required for pressing and cooling. The temperature chosen $\left(120^{\circ} \mathrm{C}\right)$ was determined as a function of the lignin plasticization, which is a compound responsible for the bond among the wood particles during the application of pressure [59]. Three compression pressure conditions were used: 6.20 MPa (900 PSI); 8.27 MPa (1200 PSI); and 10.30 MPa (1500 PSI), with pressing and cooling times of 6 minutes. 
Table 1. Methods used to characterize wood biomass, kraft lignin and briquettes.

\begin{tabular}{cc}
\hline Analysis & Standard \\
\hline Sawdust fractionation & TAPPI T257 cm-02 [45] \\
Extractives & TAPPI T264 cm-97 [46] \\
Ashes & TAPPI T15 os-58 [47]; T211 [48] \\
Carbohydrates & WALLIS et al. [49]; SCAN-CM 71:09 [50] \\
Soluble lignin & TAPPI UM 250 [51] \\
Insoluble lignin & TAPPI T222 om-97 [52] \\
Acetyl groups & SOLAR et al. [53] \\
Uronic acids & SCOTT [54] \\
Elemental analysis (CHNSO) & $\begin{array}{c}\text { TruSpec Micro-Leco Instruments 628 Series C/H/N } \\
\text { elemental analyzer with oxygen and sulfur module }\end{array}$ \\
Low and High Heating Values & DIN EN 14918 [56] \\
Briquettes bulk density & VITAL [57] \\
Rupture Modulus of Briquettes & NBR ISO 11093-9 [58]
\end{tabular}

To determine the briquetting conditions, preliminary tests relating to compaction time, cooling time and temperature were carried out. The conditions chosen were those where briquettes were obtained without cracks and with less deformation. The working moisture was $8 \%$, obtained by using a laboratory greenhouse, which was within the ideal range proposed by Kaliyan and Morey [16]. The use of moisture higher than $8 \%$ would cause the briquettes to rupture. When the raw material moisture content is very dry or above the indicated value, it can impair the packaging of the material or produce an unstable briquette, which may disintegrate when stored or transported [60], resulting in lower durability and therefore becomes more susceptible to damage [61].

The proportion of Kraft lignin mixed with the wood fines was $0 \%, 2 \%, 4 \%$, and $6 \%$, and the mass of each briquette was fixed to $20 \mathrm{~g}$, amounting 12 treatments, with 6 repetitions of each one. When an excess of the kraft lignin is used, it loses its efficiency as a binding agent and it negatively affects the briquette density [38]. Preliminary tests were performed and no more than $6 \%$ of lignin was used to avoid problems occurring with the equipment, relating to the lignin plasticization, and considering that just $2 \%$ of additives may be used in briquettes in many countries, for instance in European Union, the values above this range were used just for evaluating the potential performance delivered by the additive. In order to evaluate the quality of the briquettes and the briquetting process, visual analyzes were first carried out to observe the presence of cracks and deformations on their sides, as well as analyzes of the variations of the dimensions (height and diameter) and loss of mass in the briquetting. These visual observations were performed after the cooling time during measurements of height and diameter of briquettes. 
Unfortunately, there was not found literature data which report on the raw material investigated in this study. Therefore, several hardwood species were used as a reference for comparing the results from this work. This also indicates that this work collaborates for disseminating some unpublished scientific information on the raw material used.

Aiming to analyze results obtained in this work, the Shapiro \& Wilk test was used to verify the normality of the briquettes data [62]. The data were also submitted to analyses of variance using the Cochran test [63] to evaluate differences among treatments. The Tukey's t-test was applied at a 95\% significance level, when significant differences among the results were found.

\section{Results}

The results on the wood residues and eucalypt kraft lignin composition are described in Table 2, taking into account the chemical composition importance of the materials for energy conversion. As also previously described, there was not found literature data which report on the raw material investigated in this study, being the findings on the wood composition an important piece of information for many other works.

\section{Briquetting process}

Table 3 shows results relating to the briquetting processes on the bulk density, modulus of rupture (MOR) and heating values (LHV and HHV) of the studied

Table 2. Chemical characterization of the evaluated biomass and kraft lignin.

\begin{tabular}{|c|c|c|c|}
\hline & Analysis & Astronium concinnum biomass & Kraft lignin \\
\hline & $\mathrm{C}$ & 48.40 & 56.00 \\
\hline & $\mathrm{N}$ & 0.17 & 0.14 \\
\hline \multirow[t]{3}{*}{ Elemental analysis, $\%$} & $\mathrm{H}$ & 6.30 & 4.70 \\
\hline & $\mathrm{O}$ & 44.50 & 20.70 \\
\hline & S & 0.03 & 4.20 \\
\hline \multicolumn{2}{|c|}{ Soluble extractives, $\%$} & 6.2 & - \\
\hline \multicolumn{2}{|c|}{ Soluble lignin, \% } & 3.8 & 4.5 \\
\hline \multicolumn{2}{|c|}{ Insoluble lignin, $\%$} & 19.8 & 80.9 \\
\hline \multicolumn{2}{|c|}{ Total lignin, \% } & 23.6 & 85.4 \\
\hline & Glucan & 47.0 & 0.1 \\
\hline & Xylan & 11.1 & 0.1 \\
\hline \multirow[t]{3}{*}{ Carbohydrates, \% } & Mannan & 1.7 & 0.4 \\
\hline & Arabinan & 0.2 & 0.1 \\
\hline & Galactan & 0.7 & 0.1 \\
\hline \multicolumn{2}{|l|}{ Ash, \% } & 0.7 & 14.2 \\
\hline \multicolumn{2}{|c|}{ High heating value, $\mathrm{MJ} / \mathrm{kg}$} & 19.0 & 21.7 \\
\hline \multicolumn{2}{|c|}{ Low heating value, $\mathrm{MJ} / \mathrm{kg}$} & 17.7 & 20.8 \\
\hline
\end{tabular}


Table 3. Mean values of briquettes bulk density $\left(\rho_{a p}\right)$, modulus of rupture (MOR) and heating values (LHV and HHV) per treatment.

\begin{tabular}{ccccc}
\hline Treatments & $\bar{\rho}_{a p}\left(\mathrm{~g} / \mathrm{cm}^{3}\right)$ & MOR $\left(\mathrm{kgf} / \mathrm{cm}^{2}\right)$ & LHV $(\mathrm{M} / \mathrm{kg})$ & HHV $(\mathrm{MJ} / \mathrm{kg})$ \\
\hline T1 & $1.01 \pm 0.01^{\mathrm{f}}$ & $10.7 \pm 13.6^{\mathrm{cd}}$ & $16.3 \pm 0.00^{\mathrm{e}}$ & $18.2 \pm 0.00^{\mathrm{e}}$ \\
T2 & $1.00 \pm 0.04^{\mathrm{fg}}$ & $9.2 \pm 14^{\mathrm{cd}}$ & $16.3 \pm 0.00^{\mathrm{e}}$ & $18.2 \pm 0.00^{\mathrm{e}}$ \\
T3 & $1.03 \pm 0.03^{\mathrm{e}}$ & $9.1 \pm 12.7^{\mathrm{cd}}$ & $16.2 \pm 0.00^{\mathrm{f}}$ & $18.1 \pm 0.00^{\mathrm{f}}$ \\
A1 & $1.08 \pm 0.01^{\mathrm{d}}$ & $26.3 \pm 10.3^{\mathrm{c}}$ & $16.9 \pm 0.00^{\mathrm{a}}$ & $18.8 \pm 0.00^{\mathrm{a}}$ \\
A2 & $1.11 \pm 0.01^{\mathrm{c}}$ & $25.1 \pm 10.3^{\mathrm{c}}$ & $16.6 \pm 0.01^{\mathrm{cd}}$ & $18.4 \pm 0.05^{\mathrm{d}}$ \\
A3 & $1.13 \pm 0.01^{\mathrm{b}}$ & $22.2 \pm 9.9^{\mathrm{cd}}$ & $16.7 \pm 0.00^{\mathrm{c}}$ & $18.5 \pm 0.05^{\mathrm{bc}}$ \\
B1 & $1.13 \pm 0.03^{\mathrm{ab}}$ & $30.6 \pm 7.9^{\mathrm{c}}$ & $16.8 \pm 0.00^{\mathrm{b}}$ & $18.7 \pm 0.00^{\mathrm{b}}$ \\
B2 & $1.16 \pm 0.02^{\mathrm{a}}$ & $39.7 \pm 5.7^{\mathrm{b}}$ & $16.7 \pm 0.00^{\mathrm{c}}$ & $18.6 \pm 0.00^{\mathrm{cd}}$ \\
B3 & $1.16 \pm 0.01^{\mathrm{a}}$ & $37.3 \pm 5.8^{\mathrm{b}}$ & $16.7 \pm 0.00^{\mathrm{c}}$ & $18.6 \pm 0.00^{\mathrm{cd}}$ \\
C1 & $1.16 \pm 0.01^{\mathrm{a}}$ & $51.4 \pm 4.6^{\mathrm{a}}$ & $16.9 \pm 0.01^{\mathrm{ab}}$ & $18.7 \pm 0.05^{\mathrm{ab}}$ \\
C2 & $1.16 \pm 0.02^{\mathrm{a}}$ & $45.6 \pm 3.5^{\mathrm{ab}}$ & $16.3 \pm 0.01^{\mathrm{ef}}$ & $18.5 \pm 0.05^{\mathrm{c}}$ \\
C3 & $1.16 \pm 0.01^{\mathrm{a}}$ & $43.0 \pm 1.4^{\mathrm{b}}$ & $16.3 \pm 0.00^{\mathrm{e}}$ & $18.1 \pm 0.05^{\mathrm{ef}}$ \\
\hline
\end{tabular}

Note: (T1) pressure 900 PSI; (T2) pressure 1200 PSI; (T3) pressure 1500 PSI; (A1) 2\% Kraft lignin sample with 900 PSI; (A2) 2\% Kraft lignin sample with 1200 PSI; (A3) 2\% Kraft lignin sample with 1500 PSI; (B1) 4\% Kraft lignin sample with 900 PSI; (B2) 4\% Kraft lignin sample with 1200 PSI; (B3) 4\% Kraft lignin sample with 1500 PSI; (C1) 6\% Kraft lignin sample with 900 PSI; (C2) 6\% Kraft lignin sample with 1200 PSI; (C3) $6 \%$ Kraft lignin sample with 1500 PSI. Equal letters in the same column indicate equality between the values of the averages at a significance level of $95 \%$.

briquettes. These results are considered important parameters for the quality of the briquettes.

The modulus of rupture result was determined using software coupled with the universal test equipment called "Contenco-Pavitest". The analysis procedure was in accordance with the Brazilian standard NBR ISO 11093-9 [58] with adaptations. The equipment applies a perpendicular force on the upper side of the briquette through a piston until it ruptures. The force was determined by a preliminary test speed $\left(3.5 \mathrm{~mm} \cdot \mathrm{min}^{-1}\right)$. The briquette was tested in the vertical position, and the forces were applied parallelly, according to methodology adapted from the ABNT NBR ISO 11093-9 standard [58].

As expected, the bulk density increased, due to the agglutination and plasticization of lignin. The produced briquettes with $4 \%$ and $6 \%$, respectively treatments B and C, of incorporated Kraft lignin did not show difference related to the bulk density. However, these treatments showed difference in treatments $\mathrm{T}$ $(0 \% \mathrm{KL})$ and $\mathrm{A}(2 \% \mathrm{KL})$. In general, the use of additives in briquettes are limited to two percent, but this study showed that the inclusion of $4 \%$ and $6 \%$ of $\mathrm{KL}$ contributed to the increase in the bulk density, also $4 \%$ and 6\% (at 900 PSI) presented significant increase in the rupture modulus of the briquettes (Figure 1). On the other hand, the decrease of the rupture modulus in treatments $\mathrm{C} 2$ and C3 was observed, and it can be explained by cohesion strength among the particles with higher pressure due to the chemical composition of wood biomass 


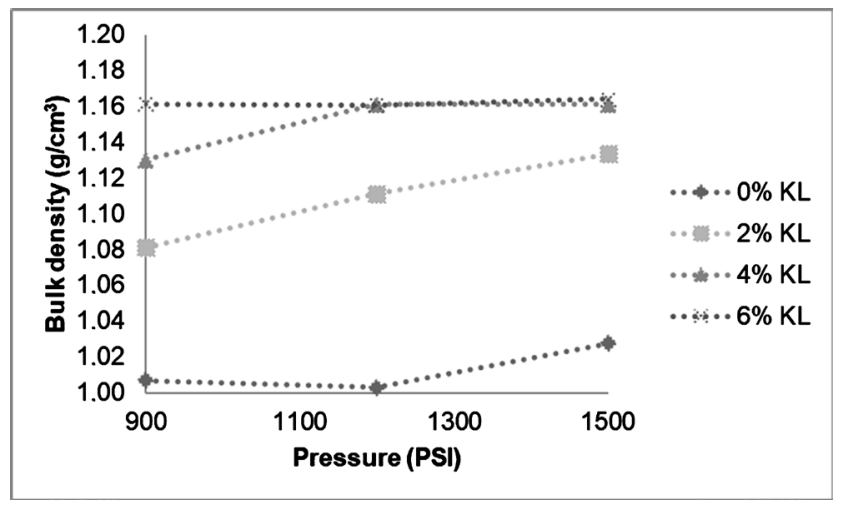

(a)

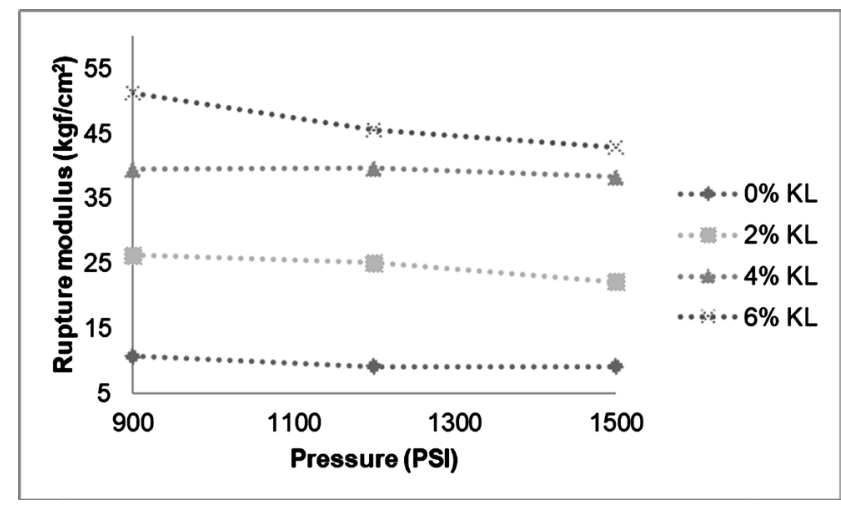

(b)

Figure 1. Properties of the briquettes, being: (a) bulk density; (b) modulus of rupture.

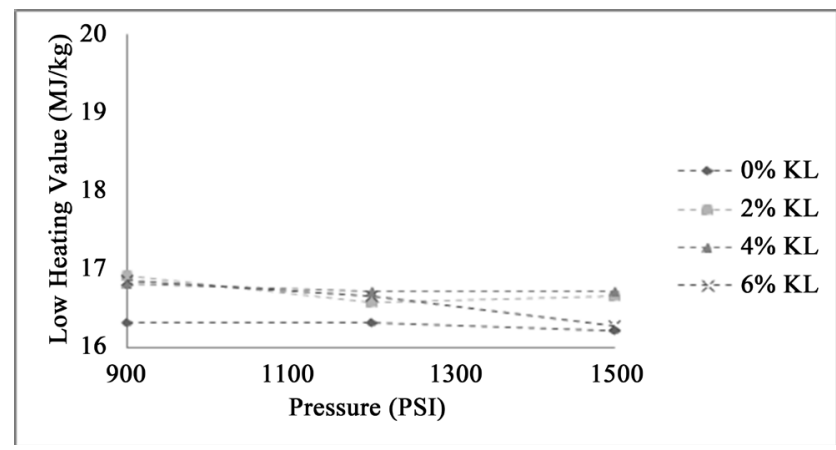

(a)

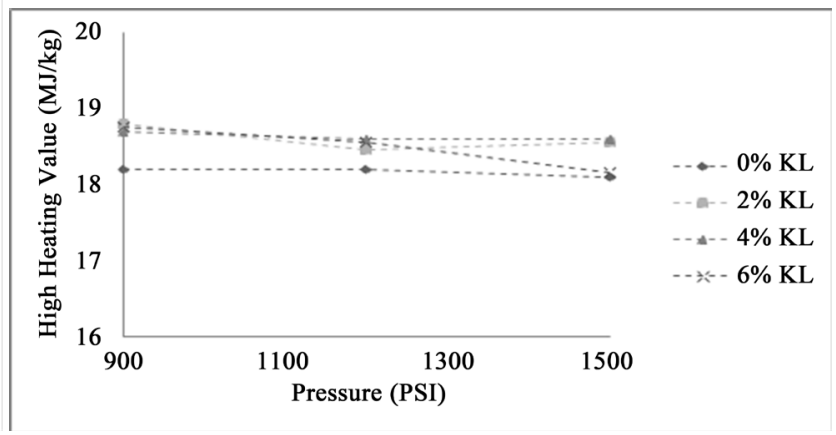

(b)

Figure 2. Astronium concinnum briquettes heating values using different concentrations of kraft lignin (KL) as additive, being (a) low heating value; (b) high heating value.

and the kraft lignin used, which possess lower content of lignin and a significant percentage of ashes on its composition, which may affect the binder process.

Analyzing the values shown in Table 3 and Figure 2 is possible to affirm that the briquettes produced in 900 PSI showed higher heating values. The lowest heating value (LHV) was obtained when using $0 \% \mathrm{KL}$ at higher pressure values (1500 PSI). The briquettes produced with $2 \% \mathrm{KL}$ presented the highest HHV, followed by the $4 \% \mathrm{KL}$ and $6 \% \mathrm{KL}$, respectively.

\section{Discussion}

The elemental analysis is a factor that depends on comparison age due to anatomical and structural changes that happen inside the biomass. It was possible to observe that wood biomass evaluated (Astronium concinnum) in this research presented similar percentage of carbon $(46.0 \%$ - 49.95\%), hydrogen $(4.8 \%$ $6.2 \%)$, nitrogen $(0.1 \%-2.4 \%)$, oxygen $(43.1 \%-46.7 \%)$, and sulfur $(0.01 \%-$ 0.05\%) when compared to the other commercial woods such as Eucalyptus spp. [64]-[71]. In this study the elemental analysis was completely measured, as previously explained, being the sum of CHNSO almost $100 \%$. In general, the oxygen is calculated by difference, which always generates values of $100 \%$ for the sum of these elements [64]-[71]. 
For the biomass, the observed extractives value was higher than that reported in the literature for Eucalyptus spp. According to research by Gomide et al. [72], Gomes et al. [73], Boschetti et al. [28] [29] hardwood species (i.e. Eucalyptus clones) present extractives up to 5\%. Extractives are correlated to the volatile compounds, which collaborate with the heating value [74].

Regarding the total lignin content, the evaluated wood presents $23.6 \%$, a lower value when compared to eucalypt (26.7\% - 31.7\%) [29] [67] [69] [72]. The carbohydrates content (60.7\%) is also lower when compared to eucalypt carbohydrates content $(64.5 \%-70.2 \%)$ analyzed by Gomide et al. [72]. The lignin content is correlated with the fixed carbon collaborating to the biomass heating value [74]-[79], being high values of this parameter desired for energy conversion.

The ash content, another important parameter to heating values, was similar to eucalypt wood (0.1\% - 0.4\%) according to Pereira et al. [35], Borges et al. [67], Morgan et al. [68], Veiga et al. [69] and Silveira [70]. The ash content is not desirable for energy application collaborating for decreasing heating value [74] [79] [80]. The ash content is also undesirable for the operation of boilers, where the biomass can be burned for converting it into energy [15] [81] [82], since ash is responsible for generating incrustations, corrosion, unscheduled stops for maintenance, for example.

The high heating and low heating values of the evaluated wood biomass were quite similar to those values described in the literature [28] [83] [84] for lignocellulosic biomasses.

Regarding to the kraft lignin composition, it is possible to verify that the studied lignin in this research has similar percentage of carbon $(49.8 \%-61.8 \%)$, hydrogen $(5.0 \%-6.5 \%)$, nitrogen $(0.1 \%-1.3 \%)$, but lower oxygen content $(29.2 \%-37.9 \%)$ and significantly higher content of sulfur $(0.8 \%-2.5 \%)$ [29] [85] [86] [87]. This information and the higher ash content directly influence in the lignin purity and energy generation. A higher ash content is disadvantageous because it decreases the heat transfer in the fuel and the biomass heating value [88] [89] [90] [91] [92], as well as increasing the corrosion of the equipment used in the process [93].

The purity is also related to the acid insoluble (Klason lignin) and soluble lignin presented in the binder material. Compared to Zhou and $\mathrm{Lu}$ [86] and Boschetti et al. [29] the studied kraft lignin used in this research is more impure, presenting lower contents of total lignin on its composition. However, the carbohydrates content presented is lower than other studies [85] [86] [87].

\section{Briquetting process}

This study pointed that when using more than $2 \%$ of additives, for instance, the use of $6 \%$ of kraft lignin showed the highest and the same values of bulk density not depending on the pressure used in the briquetting process. The studies of Boschetti et al. [28] [29] also showed that the incorporation of $6 \%$ of Kraft lignin has the best results for bulk density. This is important, because 
high-quality fuels should present high density and strength, with higher energy content [94] to burn for a longer time [8].

The rupture modulus increased after a rise in pressure and a larger amount of lignin was incorporated $(6 \% \mathrm{KL})$. When the lowest pressure value was used (900 PSI), it was observed the optimum point of the briquetting, regarding the durability and maximum rupture.

Boschetti et al. [29] studying Hymenolobium petraeum Ducke, Eucalyptus spp., and Pinus spp. briquettes also found similar results, proving that $6 \%$ of impregnated Kraft lignin gives better bulk density and rupture modulus properties. Pereira et al. [35] studying pellets confirms that the use of at least $2 \%$ of Kraft lignin can change properties of hardwood compressed materials.

The heating values indicate that the best cohesion strength of the sawdust and lignin occurred in the lower value of pressure aiming to deliver heating value. It is important to observe that the heating value is directly related to the fixed carbon content and is also associated with volatile and ash content [74]. Besides the studied lignin presents a high carbon content, which is desirable, it is also presented a high ash content, which reduces the heating value of the briquettes, mainly when the proportion of lignin addition in the briquette increases. This result indicates that the commercial kraft lignin needs to be designed for being applied to the energy application, since in the literature it is possible to observe the commercial eucalypt kraft lignin with $0.01 \%-1.4 \%$ of ash [95], $13 \%$ less than the commercial kraft lignin used in this study, which may collaborate for improving also the briquette heating value beside other strength properties.

\section{Conclusion}

In order to produce briquettes with higher heating values, it was concluded that evaluated biomass added with lower concentrations of Kraft lignin at 900 PSI generate the best results. The addition of $2 \%$ of lignin showed the best performance, however using $4 \%$ and $6 \%$ of Kraft lignin combined with higher pressure values better briquettes properties can be obtained. The use of the higher concentrations may enter in disaccordance with most standards for using additives in briquettes.

\section{Acknowledgements}

The authors are thankful for the funding from Coordenação de Aperfeiçoamento de Pessoal de Nível Superior-Brazil (CAPES)—Finance Code 001, Conselho Nacional de Desenvolvimento Científico e Tecnológico (CNPq), Fundação de Amparo à Pesquisa do Estado do Rio de Janeiro (FAPERJ), Federal Rural University of Rio de Janeiro (UFRRJ) and Federal University of Viçosa (UFV).

\section{Conflicts of Interest}

The authors declare no conflicts of interest regarding the publication of this paper. 


\section{References}

[1] Luterbacher, J.S., Azarpira, A., Motagamwala, A.H., Lu, F., Ralph, J. and Dumesic, J.A. (2015) Lignin Monomer Production Integrated into the $\gamma$-Valerolactone Sugar Platform. Energy \& Environmental Science, 8, 2657-2663. https://doi.org/10.1039/C5EE01322D

[2] Chen, F., Li, N., Li, S., Li, G., Wang, A., Cong, Y., Wang, X. and Zhang, T. (2016) Synthesis of Jet Fuel Range Cycloalkanes with Diacetone Alcohol from Lignocellulose. Green Chemistry, 18, 5751-5755. https://doi.org/10.1039/C6GC01497F

[3] Welfle, A.J. (2017) Balancing Growing Global Bioenergy Resource Demands-Brazil's Biomass Potential and the Availability of Resources for Trade. Biomass and Bioenergy, 105, 83-95. https://doi.org/10.1016/j.biombioe.2017.06.011

[4] Ji, H., Dong, C., Yang, G. and Pang, Z. (2018) Valorization of Lignocellulosic Biomass towards Multi-Purpose Fractionation: Furfural, Phenolic Compounds and Ethanol. ACS Sustainable Chemistry \& Engineering, 6, 15306-15315.

https://doi.org/10.1021/acssuschemeng.8b03766

[5] Welfle, A., Thornley, P. and Röder, M. (2020) A Review of the Role of Bioenergy Modelling in Renewable Energy Research \& Policy Development. Biomass and Bioenergy, 136, Article ID: 105542. https://doi.org/10.1016/j.biombioe.2020.105542

[6] Huang, H., Liu, J., Liu, H., Evrendilek, F. and Buyukuda, M. (2020) Pyrolysis of Water Hyacinth Biomass Parts: Bioenergy, Gas Emissions, and By-Products Using TG-FTIR and Py-GC/MS Analyses. Energy Conversion and Management, 207, Article ID: 112552. https://doi.org/10.1016/j.enconman.2020.112552

[7] Guo, Z., Wu, J., Zhang, Y., Wang, F., Guo, Y., Chen, K. and Liu, H. (2020) Characteristics of Biomass Charcoal Briquettes and Pollutant Emission Reduction for Sulfur and Nitrogen during Combustion. Fuel, 272, Article ID: 117632.

https://doi.org/10.1016/j.fuel.2020.117632

[8] World Bioenergy Association (2019) Global Bionergy Statistics 2019. World Bioenergy Association, Stockholm.

[9] Obernberger, I. and Thek, G. (2004) Physical Characterisation and Chemical Composition of Densified Biomass Fuels with Regard to Their Combustion Behavior. Biomass and Bioenergy, 27, 653-669. https://doi.org/10.1016/j.biombioe.2003.07.006

[10] Ackom, E., Mabee, W.E. and Saddler, J.N. (2010) Industrial Sustainability of Competing Wood Energy Options in Canada. Applied Biochemistry and Biotechnology, 162, 2259-2272. https://doi.org/10.1007/s12010-010-9000-6

[11] Miao, Z., Shastri, Y., Grift, T.E., Hansen, A.C. and Ting, K.C. (2011) Lignocellulosic Biomass Feedstock Supply Logistic Analysis. ASABE Conference Paper, Louisville, 7-10 August 2011, Articlr ID: 1110484. https://doi.org/10.13031/2013.37203

[12] Kenney, K.L., Smith, W.A., Gresham, G.L. and Westover, T.L. (2013) Understanding Biomass Feedstock Variability. Biofuels, 4, 111-127. https://doi.org/10.4155/bfs.12.83

[13] Karagiannidis, A. (2012) Waste to Energy: Opportunities and Challenges for Developing and Transition Economies, Green Energy and Technology. Springer Science \& Business Media, London. https://doi.org/10.1007/978-1-4471-2306-4

[14] Strezov, V. and Anawar, H. (2019) Renewable Energy Systems from Biomass: Efficiency, Innovation and Sustainability. CRC Press, Boca Raton. https://doi.org/10.1201/9781315153971

[15] Kumar, A., Kumar, N., Baredar, P. and Shukla, A. (2015) A Review on Biomass 
Energy Resources, Potential, Conversion and Policy in India. Renewable and Sustainable Energy Reviews, 45, 530-539. https://doi.org/10.1016/j.rser.2015.02.007

[16] Kaliyan, N. and Morey, R.V. (2009) Factors Affecting Strength and Durability of Densified Biomass Product. Biomass and Bioenergy, 33, 337-359.

https://doi.org/10.1016/j.biombioe.2008.08.005

[17] Ajiboye, T.K., Abdulkareem, S. and Anibijuwon, A.O.Y. (2016) Investigation of Mechanical Properties of Briquette Product of Sawdust-Charcoal as a Potential Domestic Energy Source. Journal of Applied Science and Environmental Management, 20, 1179-1188. https://doi.org/10.4314/jasem.v20i4.34

[18] Samuelsson, R., Thyrel, M., Sjöström, M. and Lestander, T. (2009) Effect of Biomaterial Characteristics on Pelletizing Properties and Biofuel Pellet Quality. Fuel Processing Technology, 90, 1129-1134. https://doi.org/10.1016/j.fuproc.2009.05.007

[19] Nilsson, D., Bernesson, S. and Hansson, P. (2011) Pellet Production from Agricultural Raw Materials-A Systems Study. Biomass and Bioenergy, 35, 679-689. https://doi.org/10.1016/j.biombioe.2010.10.016

[20] Emerhi, E.A. (2011) Physical and Combustion Properties of Briquettes Produced from Sawdust of Three Hardwood Species and Different Organic Binders. Advances in Applied Science Research, 2, 236-246.

[21] Chin, O.C. and Siddiqui, K.M. (2000) Characteristics of Some Biomass Briquettes Prepared under Modest Die Pressures. Biomass and Bioenergy, 18, 223-228. https://doi.org/10.1016/S0961-9534(99)00084-7

[22] Ahn, B.J., Chang, H.S., Lee, S.M., Choi, D.H., Taek Cho, S.T., Han, G.S. and Yang, I. (2014) Effect of Binders on the Durability of Wood Pellets Fabricated from Larix kaemferi C. and Liriodendron tulipifera L. Sawdust. Renewable Energy, 62, 18-23. https://doi.org/10.1016/j.renene.2013.06.038

[23] Rajaseevan, T., Srinivasan, V., Syed Mohamed Qafir, G. and Srithar, K. (2016) An Investigation on the Performance of Sawdust Briquette Blending with Neem Powder. Alexandria Engineering Journal, 55, 2833-2838. https://doi.org/10.1016/j.aej.2016.07.009

[24] Zhang, G., Sun, Y. and Xu, Y. (2018) Review of Briquette Binders and Briquetting Mechanism. Renewable and Sustainable Energy Reviews, 82, 477-487. https://doi.org/10.1016/j.rser.2017.09.072

[25] Lubwama, M., Yiga, V.A., Muhairwe, F. and Kihedu, J. (2020) Physical and Combustion Properties of Agricultural Residue Bio-Char Bio-Composite Briquettes as Sustainable Domestic Energy Sources. Renewable Energy, 148, 1002-1016. https://doi.org/10.1016/j.renene.2019.10.085

[26] Boudet, A.M. (2000) Lignins and Lignification: Selected Issues. Plant Physiology and Biochemistry, 38, 81-96. https://doi.org/10.1016/S0981-9428(00)00166-2

[27] Ekeberg, D., Gretland, K.S., Gustafsson, J., Braton, S.M. and Fredheim, G.E. (2006) Characterisation of Lignosulphonates and Kraft Lignin by Hydrophobic Interaction Chromatography. Analytica Chimica Acta, 565, 121-128. https://doi.org/10.1016/j.aca.2006.02.008

[28] Boschetti, W.T.N., Carvalho, A.M.M.L., Carneiro, A.C.O., Santos, L.C. and Poyares, L.B.Q. (2019) Potential of Kraft Lignin as an Additive in Briquette Production. Nordic Pulp \& Paper Research Journal, 34, 147-152. https://doi.org/10.1515/npprj-2018-0002

[29] Boschetti, W.T.N., Lopes, A.C.P., Ribeiro, R.A., Reyes, R.Q. and Carneiro, A.C.O. (2019) Kraft Lignin as an Additive in Pine and Eucalyptus Particle Composition for Briquette Production. Revista Árvore, 43, Article ID: e430201. 
https://doi.org/10.1590/1806-90882019000200001

[30] Gouvêa, A.F.G., Carvalho, A.M.M.L. and Carneiro, A.C.O. (2018) Extração da Lignina Kraft de Eucalipto e Uso para Energia. Editora Appris, Paraná.

[31] Demuner, I.F., Colodette, J.L., Demuner, A.J. and Jardim, C.M. (2019) Biorefinery Review: Wide-Reaching Products Through Kraft Lignin. BioResources, 14, 7543-7581. https://doi.org/10.15376/biores.14.3.Demuner

[32] Stelte, W., Sanadi, A.R., Shang, L., Holm, J.K., Ahrenfeldt, J. and Henriksen, U.B. (2012) Recent Developments in Biomass Pelletization-A Review. BioResources, 7, 4451-4490. https://doi.org/10.15376/biores.7.3.4451-4490

[33] Agrawal, A., Kaushik, N. and Biswas, S. (2014) Derivatives and Applications of Lignin-An Insight. The Scitech Journal, 1, 30-36.

[34] Shyamalee, D., Amarasinghe, A.D.U.S. and Senanayaka, N.S. (2015) Evaluation of Different Binding Materials in Forming Biomass Briquettes with Sawdust. International Journal of Scientific and Research Publications, 5, 1-8.

[35] Pereira, B.L.C., Carneiro, A.C.O., Carvalho, A.M.M.L., Vital, B.R., Oliveira, A.C. and Canal, W.D. (2016) Influência da adição de Lignina Kraft nas propriedades de pellets de Eucalipto. Revista Floresta, 46, 235-242. https://doi.org/10.5380/rf.v46i2.44936

[36] Mousa, E.A., Ahmed, H.M. and Wang, C. (2017) Novel Approach towards Biomass Lignin Utilization in Ironmaking Blast Furnace. ISIJ International, 57, 1788-1796. https://doi.org/10.2355/isijinternational.ISIJINT-2017-127

[37] Aamiri, O.B., Thilakaratne, R., Tumuluru, J.S. and Satyavolu, J. (2019) An "In-Situ Binding” Approach to Produce Torrefied Biomass Briquettes. Bioengineering, 6, Article No. 87. https://doi.org/10.3390/bioengineering6040087

[38] Ház, A., Jablonský, M., Šurina, I., Kačík, F., Bubeníková, T. and Ďurkovič, J. (2019) Chemical Composition and Thermal Behavior of Kraft Lignins. Forests, 10, Article No. 483 .

[39] Tumuluru, J.S., Wright, C.T., Hess, J.R. and Kenney, K.L. (2011) A Review of Biomass Densification Systems to Develop Uniform Feedstock Commodities for Bioenergy Application. Biofuels, Bioproducts and Biorefining, 5, 683-707. https://doi.org/10.1002/bbb.324

[40] Rolim, S.G. and Piotto, D. (2019) Silviculture and Wood Properties of Natives Species of the Atlantic Forest of Brazil. Ed. Rupestre, Belo Horizonte, 164 p.

[41] Lorenzi, H. (2002) Árvores brasileiras: Manual de identificação e cultivo de plantas arbóreas nativas do Brasil. 4th Edition, Instituto Plantarum, Nova Odessa.

[42] Lorenzi, H. (2002) Árvores brasileiras: Manual de identificação e cultivo de plantas arbóreas nativas do Brasil. 2nd Edition, Instituto Plantarum, Nova Odessa.

[43] Lorenzi, H. (2014) Árvores brasileiras: Manual de identificação e cultivo de plantas arbóreas nativas do Brasil. 6th Edition, Instituto Plantarum, Nova Odessa.

[44] Silva, C.E.S.S., Pace, J.H.C., Gomes, F.J.B., Carvalho, P.C.L., Reis, C.A., Latorraca, J.V.F., Rolim, S.G. and Carvalho, A.M. (2020) Comparison between Resistograph Analysis with Physical Properties of the Wood of Brazilian Native Tree Species. Floresta e Ambiente, 27, Article ID: e20190052. https://doi.org/10.1590/2179-8087.005219

[45] TAPPI (Technical Association of the Pulp and Paper Industry) (1996) Standard Method T257 cm-85. Technical Association of the Pulp and Paper Industry, Atlanta.

[46] TAPPI (Technical Association of Pulp and Paper Industry) (1997) Standard Method 
T264 om-97. Technical Association of the Pulp and Paper Industry, Atlanta.

[47] TAPPI (Technical Association of Pulp and Paper Industry) (1991) Standard Method T15 os-58. Technical Association of the Pulp and Paper Industry, Atlanta.

[48] TAPPI (Technical Association of Pulp and Paper Industry) (2002) Standard Method T211 om-93. Technical Association of the Pulp and Paper Industry, Atlanta.

[49] Wallis, A.F.A., Wearne, R.H. and Wright, P.J. (1996) Chemical Analysis of Polysaccharides in Plantation Eucalypt Woods and Pulps. CRC Publications Committee, Australia.

[50] Scandinavian Pulp and Paper and Board Testing Committee (2009) SCAN-Test Methods. Scandinavian Pulp, Paper and Board Testing Committee, Stockholm.

[51] TAPPI (Technical Association of the Pulp and Paper Industry) (1991) Standard Method. UM 250 Acid-Soluble Lignin in Wood and Pulp. Technical Association of the Pulp and Paper Industry, Atlanta.

[52] TAPPI (Technical Association of Pulp and Paper Industry) (1998) Standard Method T222 om-98. Technical Association of Pulp and Paper Industry, Atlanta.

[53] Solar, R., Kacik, F. and Melcer, I. (1987) Simple Semi-Micro Method for the Determination of O-Acetyl Groups in Wood and Related Materials. Nordic Pulp \& Paper Research Journal, 4, 139-141. https://doi.org/10.3183/npprj-1987-02-04-p139-141

[54] Scott, R.W. (1979) Colorimetric Determination of Hexuronic Acids in Plant Materials. Analytical Chemistry, 51, 936-941. https://doi.org/10.1021/ac50043a036

[55] Deutsches Institut Für Normung (DIN) (2011) DIN EN 15104. Determination of Total Content of Carbon, Hydrogen and Nitrogen-Instrumental Methods. CEN, Berlin.

[56] Deutsches Institut Für Normung (DIN) (2010) DIN EN 14918. Determination of Calorific Value. CEN, Berlin.

[57] Vital, B.R. (1984) Methods for Determining Wood Density. SIF Technical Report, Sistema de Informações Fiscais (SIF), Minas Gerais.

[58] Associação Brasileira De Normas Técnicas (ABNT) (2009) Normas técnicas NBR ISO 11093-9, Papel e cartão-Ensaio de tubetes-Parte 9, Rio de Janeiro.

[59] Filippetto, D. (2008) Briquetagem de resíduos vegetais: Viabilidade técnicoEconômica e potencial de mercado. PhD Thesis, Universidade Estadual de Campinas, São Paulo, 74 p.

[60] Quirino, W.F. (2004) Briquetagem de resíduos ligno-celulosico. Laboratório de Produtos Florestais-LPF/IBAMA, Brasília, $10 \mathrm{p}$.

[61] Moreno, A.I., Font, R. and Conesa, J.A. (2016) Physical and Chemical Evaluation of Furniture Waste Briquettes. Waste Management, 49, 245-252.

https://doi.org/10.1016/j.wasman.2016.01.048

[62] Shapiro, S.S. and Wilk, M.B. (1965) An Analysis of Variance Test for Normality (Complete Sample). Biometrika, 52, 591-611. https://doi.org/10.1093/biomet/52.3-4.591

[63] Cochran, W.G. (1950) The Comparison of Percentages in Matched Samples. Biometrika, 7, 256-266. https://doi.org/10.1093/biomet/37.3-4.256

[64] Santana, W.M.S., Calegario, N., Arantes, M.D.C. and Trugilho, P.F. (2012) Effect of Age and Diameter Class on the Properties of Wood from Clonal Eucalyptus. Cerne, 18, 1-8. https://doi.org/10.1590/S0104-77602012000100001

[65] Trugilho, P.F., Bianchi, M.L., Rosado, S.C.S., Lima, J.T. and Napoli, A. (2012) Análise elementar da madeira de clones de Eucalyptus. Biomassa \& Energia, 5, 
53-58.

[66] Pereira, B.L.C., Carneiro, A.C.O., Carvalho, A.M.M.L., Colodette, J.L., Oliveira, A.C. and Fontes, M.P. (2013) Influence of Chemical Composition of Eucalyptus Wood on Gravimetric Yield and Charcoal Properties. BioResources, 8, 4574-4592. https://doi.org/10.15376/biores.8.3.4574-4592

[67] Borges, A.C.P., Alves, C.T. and Torres, E.A. (2016) Torrefied Eucalyptus grandis. Characterization as a Biomass to Using in Industrial Scale. Chemical Engineering Transactions, 49, 283-288.

[68] Morgan, T.J., Turn, S.Q., Sun, N. and George, A. (2016) Fast Pyrolysis of Tropical Biomass Species and Influence of Water Pretreatment on Product Distributions Biomass. PLoS ONE, 11, e0151368. https://doi.org/10.1371/journal.pone.0151368

[69] Veiga, T.R.L.A., Lima, J.T., Dessimoni, A.L.A., Pego, M.F.F., Soares, J.R. and Trugilho, P.F. (2017) Different Plant Biomass Characterization for Biochar Production. Cerne, 23, 529-536. https://doi.org/10.1590/01047760201723042373

[70] Silveira, E. (2018) Acoustic Field Influence in the Kinetics of Thermochemical Degradation during Biomass Torrefaction. PhD Thesis, Universidade de Brasília, Brasília, $131 \mathrm{p}$.

[71] Silva, D.A., Eloy, E., Caron, B.O. and Trugilho, P.F. (2019) Elemental Chemical Composition of Forest Biomass at Different Ages for Energy Purposes. Floresta e Ambiente, 26, Article ID: e20160201. https://doi.org/10.1590/2179-8087.020116

[72] Gomide, J.L., Colodette, J.L., Oliveira, R.C. and Silva, C.M. (2005) Caracterização tecnológica, para produção de celulose, da nova geração de clones de Eucalyptus do Brasil. Revista Árvore, 29, 129-137. https://doi.org/10.1590/S0100-67622005000100014

[73] Gomes, F.J.B., Colodette, J.L., Burnet, A., Batalha, L.A.R., Santos, F.A. and Demuner, I.F. (2015) Thorough Characterization of Brazilian New Generation of Eucalypt Clones and Grass for Pulp Production. International Journal of Forestry Research, 2015, Article ID: 814071. https://doi.org/10.1155/2015/814071

[74] Demirbas, A. (2002) Relationships between Heating Value and Lignin, Moisture, Ash and Extractive Contents of Biomass Fuels. Energy Exploration \& Exploitation, 20, 105-111. https://doi.org/10.1260\%2F014459802760170420

[75] Demirbas, A. (2003) Relationships between Lignin Contents and Fixed Carbons of Biomass Samples. Energy Conversion and Management, 44, 1481-1486. https://doi.org/10.1016/S0196-8904(02)00168-1

[76] Demirbas, A. (2003) Relationships between Heating Value and Lignin, Fixed Carbon and Volatile Material Contents of Shells from Biomass Products. Energy Sources, 25, 629-635. https://doi.org/10.1080/00908310390212336

[77] Demirbas, A. (2007) Effects of Moisture and Hydrogen Content on the Heating Value of Fuels. Energy Sources, Part A: Recovery, Utilization, and Environmental Effects, 29, 649-655. https://doi.org/10.1080/009083190957801

[78] Fahmi, R., Bridgwater, A.V., Darvell, L.I., Jones, J.M., Yates, N., Thain, S. and Donnison, I.S. (2007) The Effect of Alkali Metals on Combustion and Pyrolysis of Lolium and Festuca Grasses, Switchgrass and Willow. Fuel, 86, 1560-1569. https://doi.org/10.1016/j.fuel.2006.11.030

[79] Tanger, P., Field, J.L., Jahn, C.E., Defoort, M.W. and Leach, J.E. (2013) Biomass for Thermochemical Conversion: Targets and Challenges. Frontiers in Plant Science, 4, Article No. 218. https://doi.org/10.3389/fpls.2013.00218

[80] Araschi, J.C., Goveia, D., Dezjacomo, G. and Prates, G.A. (2019) Evaluation of Bio- 
mass Properties for the Production of Solid Biofuels. Floresta e Ambiente, 26, Article ID: e20180433. https://doi.org/10.1590/2179-8087.043318

[81] Sommersacher, P., Bruneer, T. and Obenberger, I. (2012) Fuel Indexes: A Novel Method for the Evaluation of Relevant Combustion Properties of New Biomass Fuels. Energy \& Fuels, 26, 380-390. https://doi.org/10.1021/ef201282y

[82] Cherney, J.H. and Verma, V.K. (2013) Grass Pellet Quality Index: A Tool to Evaluate Suitability of Grass Pellets for Small Scale Combustion Systems. Applied Energy, 103, 679-684. https://doi.org/10.1016/j.apenergy.2012.10.050

[83] Bezzon, G. (1994) Síntese de novos combustíveis sólidos a partir de resíduos agroflorestais e possíveis contribuições no cenário energético brasileiro. $\mathrm{PhD}$ Thesis, Universidade Estadual de Campinas, São Paulo, 137 p.

[84] Eichler, P., Toledo, M., Vilares, M., Gomes, F., Lourega, R., Santos, G., Gomes, L. and Santos, F. (2017) Potential Assessment of Eucalyptus Grown for Biorefinery Processes. Agronomy Science and Biotechnology, 3, 1-11. https://doi.org/10.33158/ASB.2017v3ilp1

[85] Duarte, A.P., Robert, D. and Lachenal, D. (2001) Eucalyptus globulus Kraft Pulp Residual Lignin. Part 2. Modification of Residual Lignin Structure in Oxygen Bleaching. Holzforschung, 55, 645-651. https://doi.org/10.1515/HF.2001.105

[86] Zhou, X.-G. and Lu, X.-J. (2014) Structural Characterization of Kraft Lignin for Its Green Utilization. Wood Research, 59, 583-592.

[87] Gordobil, O., Moriana, R., Zhang, L., Labidi, J. and Sevastyanova, O. (2016) Assesment of Technical Lignins for Uses in Biofuels and Biomaterials: Structure-Related Properties, Proximate Analysis and Chemical Modification. Industrial Crops and Products, 83, 155-165. https://doi.org/10.1016/j.indcrop.2015.12.048

[88] Paula, L.E.R., Trugilho, P.F., Napoli, A. and Bianchi, M.L. (2011) Characterization of Residues from Plant Biomass for Use in Energy Generation. Cerne, 17, 237-246. https://doi.org/10.1590/S0104-77602011000200012

[89] Paula, L.E.R., Trugilho, P.F., Rezende, R.N. and Assis, C.O. (2011) Produção e avaliação de briquetes de resíduos lignocelulósicos. Pesquisa Florestal Brasileira, 31, 103-112. https://doi.org/10.4336/2011.pfb.31.66.103

[90] Protásio, T.P., Alves, I.C.N., Trugilho, P.F., Silva, V.O. and Baliza, A.E.R. (2011) Compactação de biomassa vegetal residual visando à produção de biocombustíveis sólidos. Pesquisa Florestal Brasileira, 31, 273-283.

https://doi.org/10.4336/2011.pfb.31.68.273

[91] Protásio, T.P., Bufalino, L., Tonoli, G.H.D., Couto, A.M., Trugilho, P.F. and Guimarães Júnior, M. (2011) Relação entre o poder calorífico superior e os componentes elementares e minerais da biomassa vegetal. Pesquisa Florestal Brasileira, 31, 122-133. https://doi.org/10.4336/2011.pfb.31.66.113

[92] Brand, M.A. (2011) Energia de biomassa florestal. Interciência, Rio de Janeiro, 114 p.

[93] Tan, Z. and Lagerlvist, A. (2011) Phosphorous Recovery from the Biomass Ash: A Review. Renewable and Sustainable Energy Reviews, 15, 3588-3602. https://doi.org/10.1016/j.rser.2011.05.016

[94] Onukak, I.E., Mohammed-Dabo, I.A., Ameh, A.O., Okoduwa, S.I.R. and Fasanya, O.O. (2017) Production and Characterization of Biomass Briquettes from Tannery Solid Waste. Recycling, 2, Article No. 17. https://doi.org/10.3390/recycling2040017

[95] Tomani, P., Axegard, P., Berglin, N., Lovell, A. and Nordgren, D. (2011) Integration of Lignin Removal into a Kraft Pulp Mill and Use of Lignin as a Biofuel. Cellulose Chemistry and Technology, 45, 533-540. 